\title{
School Safety Issues in Northern Ghana: A Way Forward
}

\author{
Anthony Kudjo Donkor* \\ Faculty of Education, University for Development Studies, P. O. Box TL 1350, Tamale Campus-Ghana \\ *Corresponding Author: Anthony Kudjo Donkor, Faculty of Education, University for Development \\ Studies, P. O. Box TL 1350. Tamale Campus-Ghana
}

\begin{abstract}
The paper hopes to lay bare the deplorable conditions under which pupils study in northern Ghana, as well as to draw the attention of policy makers and educational agencies on the need to provide safe environments for basic schools. The instruments for data collection were one-on-one interviews, focus group interviews and observation. Participants of the study include teachers, head teachers and educational personnel from the ministries. The teachers formed 5 focus groups of 10 members each. Ten (10) basic school leaders or administrators were interviewed individually. Two (2) respondents from the Ministry of Education and two (2) respondents from the Ghana Education Service were also interviewed individually. In all 64 participants took part in the study. The study revealed that Ghana did not have well-defined school safety policies for basic schools. In addition, the study confirmed the inadequate attention that policy makers in developing countries give to school safety. The bottom line is that basic schools where the bulk of the country's younger generations occupy should be provided with safe environments in order to enhance teaching and learning or better academic performance of students. The study will benefit students, teachers, parents, communities and the society as a whole.
\end{abstract}

Keywords: School Safety, Environment, Performance, Northern Ghana, Basic Schools

\section{INTRODUCTION}

Though accidents seem inevitable they are avoidable in some circumstances. The focus of the study was about the latter. It is a common phenomenon that it does not take very long for others to forget the shock and the pain that tragedies bring, however, one cannot afford to forget that the families of the victims will never forget. In addition, authority in-charge or those responsible owe it to the families of the victims to remain diligent and to do everything that one can to prevent these types of tragedies in the future (Canady, 2015).

The researcher in the capacity as the Vice Dean of the Faculty of Education, University for Development Studies, Ghana, was mandated to oversee the activities of students pursuing Basic Education course (Teacher Trainees). The students were undergoing their off-campus teaching practice as a requirement for their training as professional teachers. During the monitoring activities fifteen (15) basic schools in the Tamale Metropolis were visited. They include 10 primary schools and 5 junior high schools. The Teacher Trainees were from the Departments of Early Childhood Education and Basic Education categories. Therefore, the pupils in the schools observed include: Preschoolers, Primary and Elementary school pupils.

Though the main goal of the researcher was to observe and assess Teacher Trainees in their classrooms, the environment of the schools visited attracted attention and became a matter of concern. The commonest scenes in almost all the schools visited were: Overcrowded classrooms, dilapidated structures, inaccessible roads to the school compounds, single exit points for classrooms, eroded school compounds, etc. On the average most of the classrooms had a population of about 60-90 pupils in classrooms built for about 25-30 pupils. Dilapidated classroom walls had cracks extending from top to bottom to the extent that one could even see through the openings leading to another classroom. It was amazing that roads leading to some of the schools were not accessible by vehicles as a result of structures such as houses constructed by community members.

Some of the classrooms had single entrance or exit points. Those that have two doors of entrance or exit points were even not wide enough to accommodate the likely incidence of stampede. The soils or 
grounds of school compounds have been washed away, leaving behind wide and deep pot holes and gullies, thus impeding movement by all, especially the minors. Children, as the future leaders of every nation need more protection to survive.

\subsection{Problem Statement}

Research showed that a lot of danger looms in schools in developing countries such as Ghana, with relatively neglected preventive measures (RTI International, 2013). Of course most basic school buildings in Ghana are over aged and in dilapidated shape. The increase in population has resulted in the increase in enrolment as well, which has given rise to overcrowded classrooms. Compounds are occupied with gullies created by erosions. Most of the schools are not accessible as a result of community members' encroachment on school land. There seems to be a lack of the culture of maintenance and safety measures in the basic schools, especially in the rural areas of the country. In view of the challenges mentioned above, there arose a need to address the issues through research.

\subsection{Purpose of the Study}

Many structures as well as the environments where pupils study in basic schools in Ghana are nothing to write home about. They are in deplorable conditions. Thus, there is the need for a wake-up call and constant reminders or warnings to all stakeholders of the basic institutions, because the bulk of the younger generation occupied such facilities. It is expedient to hammer home the principle of "prevention is better than cure" or "safety first."

\section{GOAL/OBJECTIVES}

The goal of the study was to lay bare the need to provide safe environments for basic schools in Ghana, especially in the northern region.

\subsection{Research Objectives:}

The objectives of the study include the following:

1. To explore safety conditions in basic school in northern Ghana

2. To identify safety challenges in basic schools.

3. To identify safety precautions available in basic schools.

4. To provide recommendations that will prevent or minimize casualties in basic schools.

\subsection{Research Questions:}

1. What are the safety conditions in basic schools in the northern region?

2. What are the safety challenges in basic schools?

3. What are the safety precautions available in basic schools?

4. What school safety measures should be introduced in basic schools?

\section{LITERATURE REVIEW}

\subsection{Conceptual Framework}

Research indicates that lack of safety in schools affect learning (Cornell and Mayer (2010). A safe school is one that is free of danger and possible harm for students, a place in which non-educators, educators, and all learners work, teach, and learn without fear of ridicule, intimidation, humiliation or violence (Prinsloo, 2006). The concept of "school safety" has been developed and promoted by education theorists as an integral element of a good quality education (RTI, International, 2013). Prinsloo's definition omitted the fear factor of danger, which Milam et al. (2010) in their study on the linkages between perceived school and neighbourhood safety and academic achievement suggested that it was students' fear of and anxiety about violence or danger that affected their academic performance, rather than their actual experiences of the issue. Chen and Weikart (2008) stated that if students believe they are unsafe, it affects their attendance as well. Students who do not feel safe at school stay home. And when students are not in school, they do not perform academically

\subsection{Quality Education Model/EdQual Model}

School safety has been included as a dimension of educational quality in several school climate 
models, including the Child-friendly or Girl-friendly Schools Initiatives by the United Nations Children's Fund (UNICEF, 2012). In addition, there is the Quality Education Model developed by EdQual, an academic research programme funded by the UK's Department for International Development for developing country contexts. In EdQuals's model, school safety is viewed as part of an enabling school environment (RTI International, 2013). In Pinheiro's report (2006), the SecretaryGeneral of the United Nations sets forth policy recommendations for the creation of safe schools, providing governments with a platform for action.

\subsection{The Impact of Unsafe Schools on Enrolment, Attendance, and Completion}

Students stated in a survey that school violence was the main cause of absenteeism among girls. There is a gap between the average achievements of children in schools judged to be either somewhat "safe and orderly "or not safe and orderly" Mullis et al. (2012b). The safer the school (as reported by the teachers), the higher the students' average mathematics achievement (Mullis et al., 2012a). The gap between students in the" safe and orderly "and "not safe and orderly "schools was greater at the eighth grade (34 points) than at the fourth.

In a study of New York City (United States) elementary schools, Chen (2007) found that school disorder directly and indirectly affects student achievements. School disorder indirectly affects achievements through students' attendance rates. Poor attendance accounted for 45 percent of the reduction in academic achievement. In the United States, elementary school children and teachers in a suburban elementary school reported being unable to concentrate in class because of a fear of bullying (Hazel, 2010).

\subsection{Reports on School Accidents}

A stampede at a primary school in central China has left two children dead and 20 injured, because students were crowded into a toilet during the morning break when others began pushing their way in. Another report claimed the toilet's wall collapsed from the pressure of the crush. Similar deadly incidents have happened before where six children died and 25 were injured in a stampede on a school staircase in South West China in 2014 (Today Newspaper, March 22, 2017).

On March 23, 2016, five people including three Australians were injured when an under construction building of Mandali Higher Secondary School collapsed in Phulkharka, Dhading district. The building damaged by the massive earthquake of April 25, 2015, was being reconstructed. French citizen Thomas Waladrust had invested in the reconstruction of the school without the approval of the District Disaster Management Committee where the three Australians were the designers (Kathmandu, 2017).

In Ghana, six kindergarten pupils were killed by a collapsed school building in Breman Jamera in the Odoben-Brakwa District of the Central Region. The six were part of a group of KG pupils who were sitting behind their classroom at break time when the building collapsed on them. A teacher in the school claimed that the structure had developed deep cracks but it was not given the needed attention resulting in the collapse. But the District Education Coordinating Director said he had already ordered the demolition of the building after he realized it was in a dangerous state. The Minister of Education visited the victims with a team from the Ministry and the Ghana Education Service (GES) and said that the government will pay the hospital bills of the injured pupils and also that of the funeral (Amoh, 2017).

\subsection{Safety Measures in Schools}

In Oregon in the United States of America, the gymnasium roof collapsed at Highland Magnet School at Kenwood Elementary on Bend's Westside, prompting an immediate closure of all Bend-La Pine schools for two days to conduct roof assessments. The remains of the building were demolished. This was later joined by Redmond and Sisters schools. Redmond closed its schools out of caution as roof leaks were on the rise and inspections were underway. The Sisters School District also closed its buildings for further structural assessment and snow removal until buildings have been deemed structurally safe. In all three school districts, athletic contests and other activities were also cancelled.

Roof collapses have been on the rise across the region after days of heavy, wet snow piled up on roofs 
of homes, businesses and other structures. Redmond closed M.A. Lynch Elementary as a precautionary measure to assess the snow load on the roof. School authorities said they did that out of caution for student and staff safety. In addition, it has been determined that it was best to remove staff and students from the buildings. Even if students are not in immediate danger, it is better choosing to err on the side of caution and safety (Lerten, 2017).

In the wake of the death of the six pupils at the Breman Jamra KG Methodist in the Central Region of Ghana, the Ghana Education Service (GES) ordered an immediate audit of all school buildings under the service in Ghana. According to the service, the audit was to assess all public school buildings to prevent another tragedy (Ansah, 2017). The Director General of Ghana Education Service gave the order to all the District Directors and Regional Directors. The Directors were asked to liaise with the District Assemblies since education is a collective responsibility of all stakeholders and not only Ghana Education Service. It is believed that the District Assemblies have technical personnel who are the planning officers who can help get all the necessary information needed for meaningful action. The exercise was to take stock of all school buildings and statistics of all things to make sure that the incidence mentioned above does not happen again to any community in Ghana. There are several schools in Ghana where pupils are studying in dilapidated buildings, some of which are death traps. In other cases, some children are also studying under trees (Ansah, 2017).

Lack of oversight on safety issues can cost districts much in the damages awarded each year to families of children injured at school. For instance, in the Breman Jamra, Ghana incidence where the collapsed wall killed six pupils, the Minister of Education visited the victims with a team from the Ministry and the Ghana Education Service (GES) and said that the government will pay the hospital bills of the injured pupils and also that of the funeral (Amoh, 2017).

A wall collapsed at a city primary that led to the closure of 17 schools due to structural defects. A report on the Edinburgh schools scandal said it "was a matter of timing and luck" that there were no fatalities or injuries in the incident at Oxgangs Primary in January 2016 (Nicholson, 2017). The Oxgangs wall collapse was one of five "avoidable incidents" of external panels falling in strong winds at Scottish schools. A 250-page report criticized the city council, construction firms and Edinburgh Schools Partnership (ESP) - which runs the schools on the local authority's behalf - for poor construction, inadequate supervision and inefficient record keeping.

Thus, likely causes of building collapse may include, structural failure, poor supervison, carelessness, faulty design, natural causes like rainstorm, excessive loading, ignorant client, lack of structural drawings or design, hasty construction, no proper drainage, greedy client, dilapidated building etc. ( Windapo et al. 2012).

\subsection{The Role of Teachers in School Safety}

The primary responsibility of every school district is to ensure a safe and secure environment for students, staff and visitors. Schools should take an all-hazards approach that considers the best responses to a variety of emergencies. Disasters come in many forms, both natural and manmade, but school districts that are prepared for the worst are better able to get back up and running in the aftermath. Though safety inside school is ultimately the responsibility of teachers and other school staff, little do they know about the basic steps to take to ensure a safe school experience. According to Canady (2015), it is very important for students and school staff to know what to do in the event of emergency. He said that because of schools' commitment to maintaining a solid school safety team, the school should be prepared to respond to these crises in an effective manner. He suggested that a school safety team should comprise of school administrators, teachers, school employed mental health professionals, nurses, students, school resource officers and members of the fire service. This team should meet on a regular basis to discuss school safety issues, review safety plans, and to conduct "table-top" exercises in order to be properly prepared to respond to a crisis.

A principal's first job is to keep students safe. School safety starts with strong leadership, taking precautions to prevent crises in a school building, developing a plan for disasters, and acting decisively if the unthinkable does occur (Patschke, 2017).

It is believed that schools are an excellent site for the delivery of supportive services to grieving 
children and families. School personnel might be the only professionals in a position to offer timely advice on funeral attendance, or recommendations on how to help children understand death and cope with difficult feelings such as guilt. School staff can help parents find supports within the community.

Reinforcing safety is important with very young children. They need to hear that their parents or caregivers will do everything they can to keep them safe. Schools will be working to be sure that their school is a safe place for learning and having fun with friends and classmates.

Make sure students know that there are people in charge who help everyone stay safe. Children need to know that things are on course and that there are adults in charge who will help everyone involved in an accident. It is expedient to talk to students about the people who are helping to ensure that schools are safe, and share admiration with them about the great work these people are doing (Patschke, 2017).

Important information for teachers and staff to know include the following:

The manner which adults express their emotions will influence the reactions of students. So be in emotional self-control when you address anything related to accidents, grieve, guilt or lost of loved ones. Be honest with students and age appropriate with the topic. All children benefit from concrete information presented at the proper level of understanding, and maturity. Explain, but do not provide unnecessary details.

Clearly, children need to know the truth, but they do not need to hear about all of the consequences. Give them only facts that they need to know at that moment, but do not share with them your fears about the future. Young children interpret very literally; therefore you need to choose words carefully to insure the child will not misinterpret. Children will react to information differently (Patschke, 2017).

Schools are investing more in cameras and safety technology, but awareness and training are still primary, experts say. Many schools are going beyond security cameras in their efforts to prevent school shootings and other threats to students and faculty. For example, police arrested a student at Burncoat High School in Massachusetts after they were called to respond to a report of a loaded gun found in the student's locker. It was not a security camera, metal detector or a tip from social media that alerted school officials to the potential threat. Rather, a teacher overheard the student talking about shooting a police officer. The teacher brought the student to the principal's office, as other administrators searched the locker and located the gun. It was the first time in at least two decades a gun was found in the Worcester Public Schools district, and the situation could have turned out quite differently (Bidwell, 2015).

The human element of making sure that teachers and other personnel in school buildings have their ears to the ground as well as eyes widely opened every single day are the most effective way of knowing there could be potential problems in the school building or environment. According to Bidwell (2015) a significant portion of schools do not have basic protections in place. For instance, they do not provide walkie-talkies to staff. Despite the need for school personnel to be aware of potential threats, schools do not provide training on discipline policies and practices related to violence, and few schools train classroom teachers and aides to recognize early warning signs of students likely to be violent. There is a belief that the more information one has in context, the better decisions one would be able to make about how to respond to some particular incidents.

Although schools are doing better jobs with getting their sensors in place, the most important thing they can do to address safety issues, is to find a way to better manage the increasing amount of information that comes in from existing school structures, primary threats to schools, vulnerabilities and crime statistics, as well as reports of actual incidents occurring in school grounds. It is obvious that technology does not provide the whole solution to school safety issues, but also needs the human element.

\section{RESEARCH METHODS}

The research design was qualitative. The rationale for selecting a qualitative research design for the study was that qualitative studies are important for theory generation, policy development, 
improvement of educational practice, illumination of social issues, and action stimulus (McMillan and Schumacher 2010).

\subsection{Researcher as Instrument}

The researcher acknowledged himself as the primary research instrument. The researcher's interest in the study was as a result of his position as the Vice-Dean of the Faculty of Education in the University for Development Studies, where he oversees the training of pre-service teachers. The researcher had easy access to schools and participants of the study. The participants were likely to have cultivated a high level of trust toward the researcher, based on his previous contacts with many participants. The researcher continuously questioned his personal disposition and experience in order to mitigate or avert any possible influence on data analysis and interpretations. This procedure enhanced the credibility of the data findings and their reports.

\subsection{Data Collection}

Participant interviews served as one of the primary data source for the study. The researcher used two types of interviews that Creswell (2003) views as acceptable in conducting qualitative research studies. They include, individual or one - on - one interviews, and focus group interviews. The researcher audio taped focus group and individual interviews as well as made handwritten notes. Interviews were transcribed as soon as practicable after the interview session. The researcher selected a representative sample of fifty (50) teachers in the basic schools, who served as key informants. The teachers formed 5 focus groups of 10 members each. Ten (10) basic school leaders or administrators were interviewed individually. Two (2) respondents from the Ministry of Education and two (2) respondents from the Ghana Education Service were also interviewed individually. Approximately 64 participants took part in focus group and individual interviews. Data collected was used to write a descriptive narrative of events associated with school safety in basic schools in Ghana. Events reflected experiences and perceptions of teachers and school leaders and presented a holistic picture (Creswell 2003) of how school safety is handled in basic schools in Ghana, especially in the northern sector of the country.

The two main sources of data of the study were interview and observation. These sources provided reasonable quantity of narrative data. Observation proceeded concurrently with focus group and individual interviews and that facilitated triangulation of data and added to confidence in its accuracy. A multi-method, multi-source data collection strategy was used to assist the researcher to understand the phenomena under investigation, as well as provide an opportunity to corroborate data through triangulation to ascertain the accuracy and thus the reliability and validity of the data collected (Stake 1995, Merriam 1998, and Glesne 1999). The interview design involved orally questioning participants and recording their responses. The researcher used the informal conversational interview, and the standardized open-minded interview method (McMillan and Schumacher 2010).

The researcher used a cross-sectional indexing to categorize data throughout the conduct of the study. This system used codes and categories that emerged from initial data analysis. Data analysis was both literal (i.e. involving data), interpretative (i.e. what meaning the researcher ascribes to the data), and reflexive (i.e. the researcher's engagement with the data in the interpretive process) (Mason 1996). Individual and focus group interviews complement the information gathered through observation. Data analysis identified major categories and prominent themes that emerged from the data (Yin 2003) that were associated with school safety in basic schools in Ghana. The study was directed toward understanding the level of attention given to basic school safety in Ghana.

\subsection{Population of the Study}

The population of participants of the study was made up of professional teachers in basic schools, basic school head-teachers or leaders (i.e. administrators), personnel of the Ministry of Education and personnel of the Ghana Education Service. Five focus groups of ten (10) members each were formed. All participants of the five focus groups were teachers, who were in active service. In all fifty (50) teachers of basic schools in northern Ghana, were selected at random for the study. 


\section{RESUlTS AND DisCUSSIONS}

\subsection{Perceptions of Teachers and Head teachers}

The discussion of the results was based on observations and the perceptions of the participants of the study. For example, overwhelming majority of the participants did not have knowledge about School Safety.

Response from participants on what they will do in case of either man-made or natural disasters such as rainstorm, flood, fire outbreak etc. there was an over reliance on calling police and fire service or ambulance service (calling for help). However, in the context of a developing country like Ghana such facilities are not even readily available everywhere for assistance to victims of those disasters. Furthermore, a participant (teacher) simply said, "I will run away from the scene because I don't have any knowledge or skill to handle anything." That was quite pathetic. It confirmed research that though safety inside school is ultimately the responsibility of teachers and other school staff, little do they know about the basic steps to take to ensure a safe school experience (Canady, 2015).

Though about $90 \%$ of the teachers and head-teachers as participants of the study knew that they were responsible for students' safety, they had no idea of what to do in times of disaster. Other participants tried to shirk responsibility for students' safety in their schools by mentioning disaster agencies such as the police service, fire service, the government, National Authority for Disaster Management Organization (NADMO) etc.

Participants identified some threats or challenges in their schools. They include, poor electrical installations in school buildings, inaccessible roads leading to the schools for fire service vehicles to use when attending to emergency cases, cracked walls, big gutters on the compounds, single entry and exit points for overcrowded classrooms and the absence of security personnel to protect them and their students. Some schools had storey buildings with only one stairway. Participants admitted that their school environments were not in good conditions.

Teachers and head-teachers were however interested in receiving training in school safety against any kind of eventualities, self protection and the welfare of students. They said that, "Training on school safety will better equip us in case of emergency. It will help us to have control if there is disaster and it will also help us to know signs of hazards that will warn teachers and the pupils of dangers." This affirmed research to equip human elements in schools. According to Bidwell (2015) a significant portion of schools do not have basic protections in place. For instance, they do not provide walkietalkies to staff. Despite the need for school personnel to be aware of potential threats, schools do not provide training on discipline policies and practices related to violence, and few schools train classroom teachers and aides to recognize early warning signs of students likely to be violent. There is a belief that the more information one has in context, the better decisions one would be able to make about how to respond to some particular incidents.

\subsection{Perceptions of the Ministry of Education and Ghana Education Service Personnel}

They claimed to have ideas of school safety in terms of infrastructure, drainage and security. They see the need for all basic school compounds to be fenced or walled to keep away intruders such as the insane people, land encroachers etc. The Education Officers (Personnel) have seen the need for school safety but did not have any plans towards safe environments for basic schools that would enhance teaching and learning. Seeing the need for something and not doing something about it are not the same.

The personnel raised concerns about weak structures, poor drainage systems, lack of maintenance and fences, walls or watchmen. They said that most school lands have been occupied by residential buildings posing threats to the lives of teachers and students, as well as distracting teaching and learning.

\section{FINDINGS}

Data collected was used to write a descriptive narrative of the study events associated with basic school safety. Events reflected experiences and perceptions of participants of the study and presented a holistic (Creswell 2003) picture of basic school safety issues in northern Ghana. 
The study revealed that the Ministry of Education and Ghana Education Service did not have welldefined school safety policies for basic schools in Ghana.

All participants of the study have affirmed the deplorable conditions of school environments in the study area. In addition, they were all of the view that something needs to be done about the situation. The study confirmed research that a lot of danger looms in schools in developing countries such as Ghana, with relatively neglected preventive measures (RTI International, 2013).

The participants acknowledged that though they were responsible for students' safety they were not equipped with knowledge and skills to handle issues appropriately. The study confirmed Canady (2015) that though safety inside school is ultimately the responsibility of teachers and other school staff, little do they know about the basic steps to take to ensure a safe school experience. According to Canady (2015), it is very important for students and school staff to know what to do in the event of emergency.

Moreover, there was a need for human element apart from technology. According to Bidwell (2015) the human element of making sure that teachers and other personnel in school buildings have their ears to the ground as well as eyes widely opened every single day are the most effective way of knowing there could be potential problems in the school building or environment.

Although schools are doing better jobs with getting their sensors in place, the most important thing they can do to address safety issues, is to find a way to better manage the increasing amount of information that comes in from existing school structures, primary threats to schools, vulnerabilities and crime statistics, as well as reports of actual incidents occurring in school grounds. It is obvious that technology does not provide the whole solution to school safety issues, but also needs the human element (Bidwell, 2015).

\section{CONCLUSION AND RECOMMENDATIONS}

The study confirmed the inadequate attention that policy makers in Ghana give to basic school safety. The bottom line is that basic school teachers and leaders in Ghana need to be equipped with knowledge and skills in the management of school safety for confidence to prevail in the school environment. Precautionary measures may include renovation of school structures, construction of drainage systems, orientation for teachers on school safety, monitoring and evaluation (auditing) of basic schools. Furthermore, minor repair works should be done promptly, clean the environment frequently, create emergency exists and sensitize students on how to identify possible dangers. For example frequent disaster management drills, such as fire, flood etc. should be enforced in all schools as a policy.

The Ministry of Education and Ghana Education Service should set up a school safety unit to oversee safety issues in the basic schools of the nation, especially in northern Ghana. All buildings need to be monitored to ensure they do not become death traps due to weak structures. Pupils studying under trees, damaged or dilapidated school buildings, schools located within or across water logged areas should be relocated to safe grounds.

The unit should encourage safety awareness campaigns in schools and communities. It is expedient to enforce frequent auditing of school structures in the country by the safety unit of the Ministry of Education and Ghana Education Service.

School authorities should partner with community leaders as well as members in dealing with school safety issues. For example, school compounds should be well maintained to avoid or minimize the effects of erosion. Also, communities should desist from constructing houses that render school compounds inaccessible to hazard prevention organizations such as fire service, police service etc.

Teachers and head-teachers should assume a leadership role in this important, but relatively neglected field by raising awareness about the impact of school safety on educational achievement among national education policy makers and other donor agencies. It is imperative to assist the Ministry of Education and the Ghana Education Service to investigate the impact of school safety on educational achievement.

Tertiary institutions like polytechnics should join the crusade in organizing short courses and frequent seminars on school safety for all educational administrators and teachers. In addition, short sandwich 
courses should be organized for incumbent, aspiring and potential basic school teachers. The government of Ghana and Ministry of Education should make it a policy for all basic school teachers to obtained certificates in school safety from all accredited tertiary institutions. This will boost up the motivation of the tertiary institutions to introduce school safety programs that will also attract large amount of patronage like other courses.

The government, NGOs and communities should endeavour to construct more school buildings, in order to mitigate the problem of overcrowding in classrooms. Unless head-teachers and teachers are well equipped with knowledge and skills in school safety, they would not be able to manage or improve school safety conditions.

A healthy and conducive atmosphere for effective teaching and learning in the schools will be realized if the above recommendations are taken into consideration. There is the need to avoid or minimize casualties at all cost.

\section{REFERENCES}

[1] Amoh, A. (February 02, 2017). Available at: Adomonline.com, Ghana.

[2] Ansah, M. (2017). GES orders audit of school buildings after KG collapse/\#sthash.cfcZXzOB.dpuf. Available at http://citifmonline.com/Ghana.

[3] Bidwell, A. (May 21, 2015). Staff Writer. U.S. News and World Report. Available at: https://www.usnews.com/topics/author/allie-bidwell.

[4] Chen,G. (2007). School disorder and student achievement. Journal of School Violence, 6, 27-43.

[5] Chen, G. \& Weikart (2008). Student background, school climate, school disorder, and student achievement: An empirical study of New York City's middle schools. Journal of School Violence, 7, 3-20.

[6] Cornell, D. G. \& Mayer, M. J. (2010). Why do school order and safety matter? Educational Researcher, 39, 7-15.

[7] Creswell, J. W. (2003) Research design: Qualitative, quantitative, and mixed methods approaches, (2nd edn). Thousand Oaks, CA: Sage Publications.

[8] Glesne, C. (1999) Becoming qualitative researchers: An introduction (2nd edn). New York: Longman.

[9] Hazel, C. (2010). Interactions between bullying and high-stakes testing at the elementary school level. Journal of School Violence 9, 339-356.

[10] Kathmandu Post (2017). Kantipur Publications Pvt. Ltd, Nepal. Available at http://www.ekantipur.com/

[11] Lerten, B. (January 13, 2017). Available at: KTVZ. Barney.lerten@ktvz.com.

[12] Mason, J. (1996) Qualitative researching. Thousand Oaks, CA: Sage Publications.

[13] McMillan, J. H. and Schumacher, S. (2014) Research in education: Evidence-based inquiry, (7th edn). Boston, MA: Allyn and Bacon.

[14] Merriam, S. B. (1998) Qualitative research and case study applications in education. San Francisco: Jossey-Bass Publishers.

[15] Milan, A. J. Furr-Holden, C. D. M, \& Leaf, P. J. (2010). Perceived school and neighbourhood safety, neighbourhood violence and academic achievement in urban school children. The Urban Review, 42, 458467.

[16] Mullis, I.V. S., Martin, M. O., Foy, P., \& Drucker, K. T. (2012a). TIMSS 2011I International Results in Mathematics. TIMSS and PIRLS International Study Center, Boston College, Chestnut Hill, MA.

[17] Mullis, I. V. S. Martin, M. O., Foy, P., \& Drucker, K. T. (2012b). Progress in International Reading Study (PIRLS). 2011 International Results in Reading. TIMSS and PIRLS International Study Center, Boston College, Chestnut Hill, MA.

[18] Nicolson, K. (February 09, 2017). STV News, Edinburg \& East, UK.

[19] Patschke, M. (2017). National Association of Elementary School Principals - NAESP, Alexandria, VA.

[20] Pinheiro, P. (2006). Report of the Independence Expert for the United Nations Study on Violence against Children. Geneva: Secretary-General of the United Nations.

[21] Prinsloo, S. (2006). Sexual harassment and violence in South African schools. South African Journal of Education, 26, 305-318.

[22] Stake, R. E. (1995) The art of case study research. Thousand Oaks, CA: Sage.

[23] Today Newspaper (March 22, 2017). Today Newspaper. Designed by Qualtek, Ghana.

[24] UNICEF (2012). Basic education and gender equality; Child-friendly schooling approach.

[25] Windapo, A. O. \& Rotimi, J. O. (2012). Contemporary issues in building collapse and its implications for 
sustainable development. Available at www.mdpi.com/journal/buildings. ISSN 2075-5309.

[26] Yin, R. K. (2003) Case study research: Design and methods, (3rd edn). Thousand Oaks, CA:Sage Publications.

\section{AUTHOR'S BIOGRAPHY}

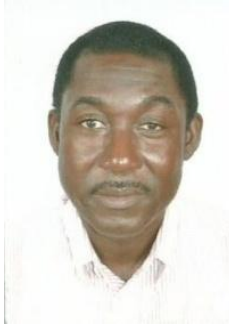

Anthony Kudjo Donkor, is a Senior Lecturer and Vice-Dean, Faculty of Education, at the University for Development Studies, Ghana. The author has accumulated practitioner experience as a classroom teacher at various levels of education such as: the primary, elementary, junior secondary, senior secondary and tertiary. He is a Co-founder and Director of an elementary school in Accra, Ghana, that provides education and support to needy families and their children. He has published many articles in areas such as social justice in education, changing the context of learning for a better education, parental support for children's education, basic school leadership and several others. Research interests are: Multi-cultural Education, Parental Involvement in Education, Educational Leadership, School-Community Relations, Educational Reforms, Organizational Behaviour and Research Methods.

Citation: Anthony Kudjo Donkor. "School Safety Issues in Northern Ghana: A Way Forward". International Journal of Humanities Social Sciences and Education (IJHSSE), vol 5, no. 2, 2018, pp. 88-97 doi: http://dx.doi.org/10.20431/2349-0381.0502010.

Copyright: (C) 2018 Authors. This is an open-access article distributed under the terms of the Creative Commons Attribution License, which permits unrestricted use, distribution, and reproduction in any medium, provided the original author and source are credited. 